\title{
SPEECH ACTS OF U.K. PRIME MINISTER BORISH JOHNSON'S SPEECH
}

\author{
Risma Ratri Rahayu' ${ }^{1}$ Ula Nisa El Fauziah² \\ 1,2 IKIP Siliwangi \\ ${ }^{1}$ risma.r.r@ student.ikipsiliwangi.ac.id, ${ }^{2}$ ulanisa@ikipsiliwangi.ac.id
}

\begin{abstract}
This research was to investigate speech acts of Borish Jonshon's speech concern in the illocutionary act and the use of speech act analysis by Hymes (2014). The speech was held in Prime Minister's office and Borish Johnson has used a national TV address at $8.30 \mathrm{p} . \mathrm{m}$. The data of this research taken from the script and speech video of the U.K. Prime Minister named Borish Johnson on 23 March 2020 which talked about Covid-19. The research applied descriptive qualitative as a method and hold in Yule's speech act theory. Based on the analysis, the researcher was found and analyze 222 utterances. Those are consist of, $36 \%$ representative, $33 \%$ declarative, $16 \%$ directive, $9 \%$ expressive, and $6 \%$ commissive. As the result was representative is the highest use of the illocutionary aspect found in this research. It can be seen that Borish Johnson hoped that his audiences would follow what he said to reduce the coronavirus disease - 19 .
\end{abstract}

Keywords: Pragmatics, Speech Act, Covid-19

\section{INTRODUCTION}

Speech is a public speaking activity. Mufiah and Rahman (2018) state that speech is a public speaking activity in the formal talk form and performed by a leader to deliver his expression. Speech is not only used by a leader but usually used by a famous person or a leader of one country, institutions, or others too. The speech proposed is for transferring information that is important or should be discussed. In the speech, we can deliver much information such as the speech of the declaration name of new institutions or victory speech of a new president or the others.

When people want to speak they will plan any words that synchronize by the context but sometimes meaning by the form of words and the meaning by the words are different. To understand the meaning in certain speech we need pragmatics competence. Pragmatics is a branch of linguistic that is a study about the condition of meaning and context of utterances (Angginie et al, 2019). So, pragmatic has two keywords; meaning and context. In this case pragmatic can do by speaker or writer also can be explained by a listener or reader. Pragmatic is a study of speaker meaning (Yule, 1996:3). According to Purwita Sintamutiani et al. (2019) said that speaker, listener, or other aspects are needed to study of language operation about the context in utterances. There are so many aspects of pragmatic include speech acts.

Table 1. Example of Pragmatics (Mufiah and Rahman, 2018)

\begin{tabular}{|c|c|c|}
\hline Sentence: Wl & it? & \\
\hline & Literal & Pragmatic \\
\hline Meaning & What time is it? & Why are you coming late? \\
\hline Response & Tell a time. (e.g. it is...) & Tell a reason. (e.g. because...) \\
\hline
\end{tabular}




\section{Speech Acts Theories}

One of the components of language communication is Speech Act (Rosyidi, Mahyuni, and Muhaimi 2019). A Speech act is an act performed when saying something. Yule (1996:48) as cited in (Putri and Ramendra 2019) said speech act is an action that delivers by utterances. According to Rudiawati and Fitria (2018), speech acts can be simple is about how the language is used to meet our needs in speech. Because by speech we can get much information, give or get advice, ask questions, do a plan or promise and others.

\section{Types of Speech Acts}

Yule (1996:48) as cited in Rudiawati and Fitria (2018), states that speech acts has three acts; locutionary act, illocutionary act, and perlocutionary act.

a. Locutionary act is the basic act of utterances. Locutionary Act is an act that producing a meaningful linguistic expression. Yule (1996) in Hidayat (2016) states that locutionary act is the act of producing meaningful utterances. Below is the following sentence of illocutionary act example:

(1) It is so hot in this room.

(2) The box is heavy.

Two sentences above have represented the actual condition. Which the first sentence presents the temperature of the room, and the second sentence presents the weight of the box.

b. An illocutionary act is an act that does by a speaker with a purpose to communicate to the listener. Yule (1998) in Hidayat (2016) states that the performed of illocutionary act is came from the communicative force of an utterance. Such as promising, apologizing, offering, and others. Hidayat (2016) states that the illocutionary act also called "an act of doing something in saying something". Here the example by a sentence of the illocutionary act:

(1) It is so hot in this room.

(2) The box is heavy.

Based on the example above, the first sentence presents a request to turn on the air conditioner, and for the second sentence present a request to help her or his to lifting the box.

c. The perlocutionary act is an act of interpreting what the speaker says. Hufford and Heasley (1983:250) in Hidayat (2016) states that the perlocutionary act is the activity carried out by a speaker when making an utterance in a certain effect on the listener, hearer, and others. For example:

(1) It is so hot in this room.

(2) The box is heavy.

The first sentence is uttered by someone while turn on the air conditioner and the second sentence is done by someone while lifting the box.

\section{Illocutionary Act Classification}

Appropriate to Yule (1996) as cited in Rudiawati and Fitria (2018) illocutionary act is an act which achieves by communicative force of an utterance and in Yule's book theory namely Pragmatics: Speech Acts Classification, states that speech acts can be divided into five types; declaratives, representatives, expressives, derictives, and commisives.

\section{Declaratives}


These aspects are used to say something by utterances and it can change the world or make it so. Such as declaration.

Examples: You are out!, Now I pronounce you to be husband and wife.

The example of utterance is represented speaker who declares someone. In the first utterance, the speaker is declaring someone to go out of the room, and the second utterance is to declare a couple to be an official relationship.

2. Representatives

These kinds of speech acts have proposed to telling something true, untrue or the speaker believes to be the case or not. Statement of fact, assertions, conclusions, descriptions, those are the example of speaker representing this aspect.

Examples: The earth is flat, Chomsky did not write about peanuts.

The example above represents the speaker's assertions about the earth and Chomsky. The speaker has an opinion that the earth is flat and Chomsky did not write about peanuts.

3. Expressives

These aspects of the speech act are stating about what the speaker feels. Expressives aspect is like statements of pleasure, pain, like, joy, sorrow, thanking, welcoming, apologizing, congratulating, or deploring.

Examples: Sorry that is my mistake, Happy graduation!

According to the example utterance above, the utterance represents the speaker's expression that the speaker is apologizing and congratulating someone.

4. Directives

These aspects are used by a speaker to ask someone else to do something. When performing directives speaker tries to make a hearer commit with him or herself. It also a negative or positive form depends on the speaker's wants. Such as command, order, request, invite, advice, beg, and suggestion.

Examples: Do not touch my phone, Tomorrow you must be here at 7 p.m.

Based on the examples above, the example represented the speaker's requests that the listener should do something. That is to do not touch the phone, and the listener must stay there at 7 p.m tomorrow.

5. Commissives

These aspect has proposed to commit some future actions by speakers. They promise, treat, plan, refuse, and pledge.

Examples: I will be back!, We won't do that!

From the example above, the example utterance represents that the speaker promises that the speaker will be back, also in the second sentence speaker is promises that the speaker would not be doing something.

In this research, the researcher chooses to analyze Borish Johnson's speech as prime minister of the United Kingdom and concern about the illocutionary aspect because his speech was about Coronovirus which is very popular nowadays, and his position also quite fluently. It makes the researcher feel interested. So, the researcher put the title for this research is Speech Acts U.K. Prime Minister Borish Johnson's Speech.

\section{Speech Act In Non-English as First Language}

English is accepted by various countries with different positions, there is a foreign language, first language, or a second language. When utterance comes to speech act in the countries which not accepted English as First Language there are several things to consider. The factors are idiomatic expressions and cultural norms (Hidayat 2016). Because of the differences in the 
factor in each country, the learners need to understand the first language first to be able to transfer to other languages.

Speech is a public speaking activity, which means that speech is closely related to speaking. In order to understand the messages in speech, Hymes (1974) in Hidayat (2016) proposed the SPEAKING model of analysis. Hymes stated that learning vocabulary and grammar are not only things that need to speak a language properly, but the context in which word is used also needs to learn. Below is the SPEAKING model of analysis by Hymes (1974) :

1. $\mathbf{S}$ - Setting and Scene. The setting is presents the time and place and the scene presents the environment situation or the type of activity. Such as meeting room, at night, friendly conversation, and others.

2. $\mathbf{P}$ - Participants. Participants present who is joined to the speech includes the speaker, audience, inter-viewer, caller, performer.

3. E - Ends. Ends present about the purpose of the speech itself with any outcomes, function, or effects of the speech.

4. A-Act Sequence. Act sequence present about the order of events that took place during the speech.

5. K - Key. This part presents the key, tone, mood, or manner of the speech. Such as serious, formal, and others.

6. I - Instrumentalities. Instrumentalities are present about the form and style of the speech being given which can be a channel (verbal, nonverbal, face to face, telephone, SMS) and a code (emoticons, dialect, and language variety).

7. $\mathbf{N}$ - Norms. This part defines what is socially acceptable at the event.

8. G - Genre. Genre presents the type of speech. Such as greeting, joke, apology, and others.

\section{METHOD}

Descriptive qualitative is the method to find out the result of this research because the data of this research are in the form of words and utterances. This research aim is to describe the kind of speech acts that found and used in Borish Johnson's Speech. The data for this research was from the script and speech video of Borish Johnson's speech. The script was from www.gov.uk and the speech video is on youtube BBC.

In order to conduct the result of the research as a researcher is need a step to do as the process to collect the data. There are following steps to collect the data:

1. Search the speech video and script

2. Watch and observe the video to know the utterances

3. Read and understanding the script

4. Determine the place, participants, time, and others based on the SPEAKING model to make easier at understanding the meaning of the speech

5. Determine the type of illocutionary acts that found by giving a block of color in each utterance

6. Analyze the data

7. Input the result into a table as a conclusion of the research 


\section{RESULTS AND DISCUSSION}

\section{Results}

The data of this research was taken from a script in https://www.gov.uk/government/speeches/pm-address-to-the-nation-on-coronavirus-23march-2020 and the speech video is from https://www.bbc.com/news/uk-52011928.

Based on the SPEAKING model to do speech analysis which stated by Hymes (1974), the researcher found all the SPEAKING models. Below is the speech analysis based on the SPEAKING model :

S - Setting and Scene: The setting of this speech is located in Prime Minister's office at 10 Downing Street and for the scene of this speech is formal because the one who gave the speech was the Prime Minister and conveyed to all parts of the United Kingdom and delivered about that were happening in the United Kingdom.

P - Participants: The participants in this speech are Prime Minister, British people, doctors, nurses, and all important parts of England country such as the police and army.

E - Ends: The purpose of this speech are to telling all British people not to go anywhere to reduce the rate of spread of the disease, thanks to medical personnel, and calls on state officials to maintain security during the disease.

A - Act Sequence: The order of events in this speech is only one that is the prime minister self who is recording the speech on national television and told about the disease.

$\mathbf{K}-$ Key: The key to this speech is formal and serious.

I - Instrumentalities: The form and style of this speech are delivered by channel in one of the national television named BBC.

$\mathbf{N}$ - Norms: The socially that found in the speech is the legal norm.

$\mathbf{G}$ - Genre: The genre or type of speech are representatives.

Table 2. Frequency of Illocutionary Acts in Borish Johnson's Speech

\begin{tabular}{llcc}
\hline \multicolumn{2}{c}{ Illocutionary Act } & Utterances & Percentage \\
\hline 1. & Declaratives & 74 & $33 \%$ \\
\hline 2. & Representatives & 79 & $36 \%$ \\
\hline 3. & Expressives & 20 & $9 \%$ \\
\hline 4. & Derictives & 36 & $16 \%$ \\
\hline 5. & Commisives & 13 & $6 \%$ \\
\hline & TOTAL & 222 & $100 \%$ \\
\hline
\end{tabular}

The table above shows an aspect of illocutionary acts found in Borish Johnson's Speech. All of the types of illocutionary has found, start from declarative until commisive aspect but the frequency in each aspect is different.

\section{Discussion}

Sees in the result above, the highest frequency of illocutionary aspect hold by representatives aspect with quantities $36 \%$ and the shortest aspect is commisive with $6 \%$ of quantities of utterances. Here are the discussion of each illocutionary types which sorted from the highest percentage to the lowest percentage; 
Table 3. Examples of Illocutionary Acts Statement

\begin{tabular}{|c|c|c|c|c|}
\hline No & $\begin{array}{c}\text { Illocutionary Act } \\
\text { Types }\end{array}$ & & Statement & $\begin{array}{c}\text { Felicity } \\
\text { Conditions }\end{array}$ \\
\hline \multirow[t]{7}{*}{1 . } & \multirow{7}{*}{ Representatives } & 1) & $\begin{array}{l}\text { The Coronavirus is the } \\
\text { biggest threat this } \\
\text { country has faced for } \\
\text { decades }\end{array}$ & $\begin{array}{l}\text { Statement of } \\
\text { fact }\end{array}$ \\
\hline & & 2) & $\begin{array}{l}\text {... and this country is } \\
\text { not alone }\end{array}$ & Assertions \\
\hline & & 3) & $\begin{array}{l}\text { And yet it is also true } \\
\text { that there is a clear } \\
\text { way through }\end{array}$ & $\begin{array}{l}\text { Statement of } \\
\text { fact }\end{array}$ \\
\hline & & 4) & $\begin{array}{l}\text { So, it's vital to slow the } \\
\text { spread of the disease }\end{array}$ & Assertions \\
\hline & & 5) & $\begin{array}{l}\text { From this evening I } \\
\text { must give the British } \\
\text { people a very simple } \\
\text { instruction }\end{array}$ & Inform \\
\hline & & 6) & $\begin{array}{l}\text { No Prime Minister } \\
\text { wants to enact } \\
\text { measure like this }\end{array}$ & Assertion \\
\hline & & 7) & $\begin{array}{l}\text { With the time you buy, } \\
\text { by simply staying at } \\
\text { home... }\end{array}$ & Description \\
\hline \multirow[t]{4}{*}{2.} & \multirow{4}{*}{ Declaratives } & 1) & $\begin{array}{l}\text { If you don't follow the } \\
\text { rules police will have } \\
\text { the powers to enforce } \\
\text { them }\end{array}$ & Declare \\
\hline & & 2) & $\begin{array}{l}\text { Parks will remain } \\
\text { open for exercise but } \\
\text { gatherings will be } \\
\text { dispersed }\end{array}$ & Declare \\
\hline & & 3) & $\begin{array}{l}\text {...of national } \\
\text { emergency to stay at } \\
\text { home, protect our } \\
\text { NHS and save lives }\end{array}$ & Declare \\
\hline & & 4) & $\begin{array}{l}\text { We are accelerating } \\
\text { work on vaccine }\end{array}$ & Declare \\
\hline
\end{tabular}




\begin{tabular}{|c|c|c|c|c|}
\hline & & 5) & $\begin{array}{l}\text {... and we are buying } \\
\text { millions of testing kits }\end{array}$ & Declare \\
\hline \multirow[t]{3}{*}{3.} & \multirow{3}{*}{ Derictives } & 1) & You must stay at home & Command \\
\hline & & 2) & $\begin{array}{l}\text { Each and everyone of } \\
\text { us is now obliged to } \\
\text { join together }\end{array}$ & Order \\
\hline & & 3) & $\begin{array}{l}\text { We have been asking } \\
\text { people to stay at home } \\
\text { during this pandemic }\end{array}$ & Advice \\
\hline \multirow[t]{2}{*}{4.} & \multirow[b]{2}{*}{ Expressives } & 1) & $\begin{array}{l}\text { I want to thank } \\
\text { everyone... }\end{array}$ & Thanking \\
\hline & & 2) & $\begin{array}{l}\text { We will beat it } \\
\text { together }\end{array}$ & Apologizing \\
\hline \multirow[t]{2}{*}{5.} & Commisives & 1) & I can assure you... & Promise \\
\hline & & 2) & $\begin{array}{l}\text { If the evidence shows } \\
\text { we are able to }\end{array}$ & Plan \\
\hline
\end{tabular}

\section{CONCLUSION}

In understanding the hidden messages in utterances especially speech can by pragmatics and speech act. Without those aspect, we can unpleasant and missing the meaning of one utterance moreover the listener is not careful. This research was based on the George Yule Speech Acts theory. According to Yule, there are five types of illocutionary act, there are; declaratives, representatives, expressives, derictives, and commisives. This research was analyzed by utterances in Borish Johnson's speech and found 222 utterances with all types of illocutionary was found in this research.

Based on the result above the researcher found the highest speech acts often used in Borish Johnson Speech on 23 March 2020 are representatives with 79 utterances as in percentage is $36 \%$. It means that the speech is more giving an assumption about the true or false and has potential to represent what speaker feel, the second following with declaratives with 74 utterances or $33 \%$, the third position is derictives with 36 utterances or $16 \%$, next is expressives is 20 utterances with $9 \%$ in percentage, and the last is commisives with 13 utterances as in percentage is $6 \%$.

\section{ACKNOWLEDGMENTS}

Allhamdulillahirabbilalamin all praises to Allah SWT and our prophet Muhammad S.A.W which always gives strength and spirit during making this research entitled Speech Acts of U.K. Prime Minister Borish Johnson's Speech. The researcher also delivers high appreciation to all 
people who contribute to this research until published especially to the researcher supervisor. The researcher also knows that this research is not perfect but this research hope can help as a reference for the next researcher or readers.

\section{REFERENCES}

Aulia. A. V, Santika. T, and El Fauziah. U. N. 2019. Analysis About Politeness In Barbie As The Princess And The Pauper Movie.

Hidayat, A. 2016. Speech Acts : Force Behind Words. 9(1):1-12.

Mufiah, N. S, Nur Rahman. M. Y. 2018. Speech Acts Analysis of Donald Trump's Speech.

Purwita Sintamutiani, Diah, Dias Fitriani, and Ratih Inayah. 2019. An Analysis of Speech Act Classification In Beauty And The Beast. 2(4).

Putri, I. A. P. A. D. P., and D. P. Ramendra. 2019. An Analysis of Speech Act Used In Harry Potter And The Goblet Of Fire Movie. Vol. 3.

Rosyidi, A.Z., Mahyuni, and Muhaimi. 2019. Illocutionary Speech Acts Use by Jokowidodo in First Indonesia Presidential Election Debate 2019. International Journal of Multicultural and Multireligious Understanding 6(2):735.

Rudiawati, R and Fitria, V. 2018. Speech Act In Indonesias' Shampoo Advertisment. Vol. 1.

The Script Retrieved from https://www.gov.uk/government/speeches/pm-address-to-thenation-on-coronavirus-23-march-2020 